Int. J. Electrochem. Sci., 14 (2019) $1372-1387$

\title{
Corrosion Control of Copper in Nitric Acid Solution using Chenopodium Extract
}

\author{
M. M. Motawea ${ }^{1}$, A.El-Hossiany ${ }^{2}$, A. S. Fouda ${ }^{3, *}$ \\ ${ }^{1}$ Department of Chemistry, College of Science, University of Bisha, Bisha, Kingdom of Saudi Arabia \\ and Misr Higher Institute of Engineering \& Technology Mansoura, Egypt \\ ${ }^{2}$ Chemist, Delta Fertilizers Company in Talkha, Egypt. \\ ${ }^{3}$ Chemistry Department, Faculty of Science, Mansoura University, Mansoura-35516, Egypt, \\ *E-mail: asfouda@hotmail.com
}

doi: $10.20964 / 2019.02 .29$

Received: 9 October 2018 / Accepted: 6 December 2018 / Published: 5 January 2019

Chenopodium extract was examined as a corrosion inhibitor for $\mathrm{Cu}$ in $1 \mathrm{M} \mathrm{HNO}_{3}$ by utilizing chemical and electrochemical techniques. The results displayed that Chenopodium extract (CE) could play important role as a corrosion inhibitor for $\mathrm{Cu}$ in $1 \mathrm{M} \mathrm{HMO}_{3}$. The protection efficiency (PE) increases with rise of the $\mathrm{CE}$ concentrations (reached to $>92 \%$ ) due to the adsorption of the CE molecules on the $\mathrm{Cu}$ surface. Furthermore, it was recognized that the adsorption obeyed Langmuir isotherm. The polarization data showed that this $\mathrm{CE}$ acts as mixed kind inhibitor. In addition some thermodynamic data were measured and explained.

Keywords: Corrosion inhibition, $\mathrm{Cu}, \mathrm{HNO}_{3}$, Chenopodium extract, Adsorption

\section{$\underline{\text { FULL TEXT }}$}

(C) 2019 The Authors. Published by ESG (www.electrochemsci.org). This article is an open access article distributed under the terms and conditions of the Creative Commons Attribution license (http://creativecommons.org/licenses/by/4.0/). 